\title{
APPLYING THE INTERNET OF THINGS IN THE DEVELOPMENT OF MANAGEMENT ACTIVITIES IN SMART BUILDINGS
}

\author{
Ola Zygoń \\ Czestochowa University of Technology \\ Faculty of Management
}

\begin{abstract}
The goal of the article is to define proper determinants of smart buildings and discuss all previous terms related to this concept. The paper also presents areas of application of the Internet of Things (IoT) and discusses the seven stages of creating smart buildings. It also indicates the directions of development of information technology that is used to operate smart buildings and implements the IoT solutions for this purpose. In addition, the article stresses the importance of cooperation of designers and stakeholders at all the stages of the smart building designing.
\end{abstract}

Keywords: intelligent building management, Internet of Things, smart building status, supporting systems

DOI: $10.17512 /$ znpcz.2018.1.09

\section{Introduction}

The idea of smart buildings was developed over the period of the last 20-30 years of the previous century. The term „smart building” is associated with a modern facility fitted with numerous sensors and automatic systems of alarming, monitoring and controlling. Constant technological progress creates new possibilities to be applied in the construction industry. In the course of designing a smart building, its infrastructure, communication systems, technological solutions, systems, and the resources of the whole facility are treated comprehensively. The proper functioning of the applied solutions supports sustainable development and increases the operational performance of particular devices. This statement refers exclusively to the technical level of technologies that are applied in the building. New information technologies, innovative solutions, growing popularity of mobile tools cause significant changes in the demands of consumers, which in turn makes the producers who want to remain on the market offer newer products and services (Zygon 2017, p. 197-200). The Internet of Things, which is applied in nearly every industry, turns out to be a better possibility for producers to reach customers. Smart buildings utilise solutions which, with the use of the Internet of Things, may be introduced to improve the quality of man's living and working space.

The first smart building in the world was The City Place Building in Hartford in the United States in 1983 (Robathan 1989). Initially, the definition of a smart building meant a facility of high technical quality where management systems 
were applied. However, it is not important for users of a smart building how the equipment responsible for the service was created, but how it increases the comfort of their lives. Despite the time lapse, the concept of a smart building has not been precisely defined. Robathan P. proposed a few definitions of a smart building:

- "a smart building creates conditions that maximise the efficiency of building usage and simultaneously allow for effective management of resources at minimum exploitation costs",

- "a smart building ensures productive, economical and effective conditions to optimise four fundamental construction elements: systems, services and management and their mutual dependencies",

- "a smart building »helps« its owners and administrators achieve their goals considering the cost, comfort, security, long-term adaptiveness and market attractiveness".

The European Smart Building Group defines a smart building as a facility that "maximises action efficiency of its users and allows for an efficient (effective) resource management at minimum operating costs". Another definition describes a smart building as the one that "combines best projects, materials, systems and technologies to create a facility that will satisfy or exceed operating expectations of its co-dwellers" (Clements-Croome 2014, p. 11-12).

Analysing the present definitions of a smart building one can state that it is a facility that is equipped with advanced systems that enable the collection of a huge amount of data, their analysis, exchange, merging and making appropriate decisions based on the available information. If the facility is designed properly, at the initial stage of the design process, it generates better results at later stages. Appropriately selected systems and installations influence the security, system efficiency, data protection of those who use the solutions applied in the smart building. The platform that unites all the programs and systems supporting the functioning of a smart increases its efficiency in the scope of security, operating efficiency, energy consumption and data protection. It is assumed that the systems used in a smart building cooperate with devices that create their own platform. This platform enables the gathering, coordination, and exchange of the data received from various systems that support the smart building. The proper functioning of the platform provides transparent access to data gathered in real time and intuitive visualisation of indicators on control panels, adjusted to particular stakeholders (Brown 2016).

\section{Application of the Internet of Things in construction industry}

The Internet of Things is a developing technology. Therefore, it is applied in modern technological domains. IoT makes use of savings and reliability technology, particularly for the operations of data gathering and security, which are at the disposal of an organisation (in this case the facility), i.e., cloud computing. It applies IT technology, software agent-based technology (Kiełtyka, Niedbał 2013, p. 293-307), semantic networks technology, multimedia techniques and technologies 
(Kiełtyka 2009, p. 25-33; Kieltyka 2017, p. 93-106), virtual operation organisation technology (Kierzkowski 2013, p. 4-8), etc. It means that IoT plays a significant role in the numerous branches of economy. Example of sectors in which IoT solutions are used are presented in Figure 1.

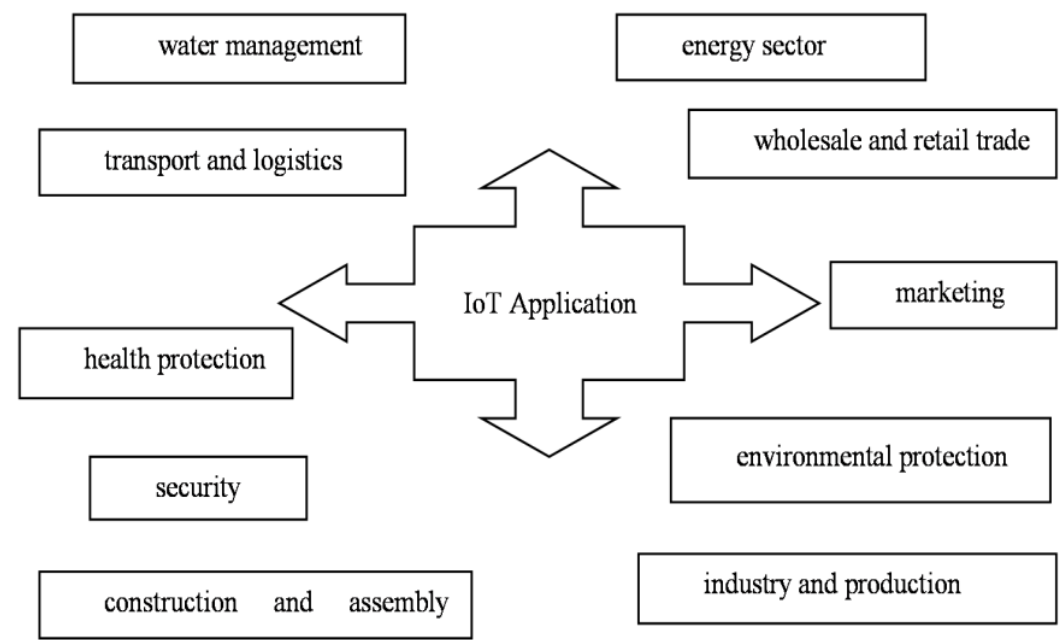

Figure 1. Sectors in which the Internet of Things solutions are applied

Source: Own elaboration based on (Vermesan, Friess (eds.) 2014, p. 12, 73)

Currently, the IoT has wide-ranging applications in economy. Therefore it can affect all of its sectors. The IoT can be applied in almost any domain, allowing for the improvement of a range of support systems, e.g., facility, manufacturing, security, environmental protection. Telecommunication network platforms provide a possibility to gather and analyse data (e.g., from the smart building area) and make decisions on this basis. Using teleinformatic networks allows for the development of a comprehensive platform of the IoT services, decreasing at the same time the market entry cost of a new product or service offered by the company. It is difficult to imagine the influence of the Internet on facilities, and particularly their construction. However, a smart building changes the perception of the Internet of Things. In the course of designing and constructing residential or production buildings, engineers take advantage of the IoT possibilities to develop, among others, building and industrial control systems, assets management, emergency power supply, lighting, analysis and metering. Therefore, proper tools need to be applied for this purpose. Business analytics provides techniques and tools that allow for the effective management of useful knowledge. Modern solutions, in turn, are effective in making real-time decisions on quick and large data streams. Enterprises that would like to incorporate the IoT solutions into their business model should not be afraid of lacking skills or indispensable technology. Probably, the tools that are supposed to release business values in the Internet of Things are already applied by enterprises. Competences and tools are analogous to the ones used in Big Data solutions. 
A growing interest can be observed among investors in smart buildings fitted with highly-integrated utility systems. A cooperation of designers is required to achieve this goal.

In modern constructions all utility systems such as:

- lighting,

- electrical installation,

- security and fire protection,

- HVAC systems,

- low voltage installations and other

are interconnected, and to a certain extent they even intersect. Thus, they should not be designed separately. Comprehensively integrated systems cooperate with one another, offering at the same time much more functions. That is why the cooperation of engineers and experts is required in the process of their development. Only then will they be able to meet all the demands of the owners and users of such facilities. The Industrial Internet of Things (IIoT) has gained popularity among the customers of engineering and consulting companies, which allowed them to be considered experts in this domain (Bhavesh 2015). The IIoT enables to specify precisely the functions of devices, designing and developing installations of facilities. Customers of engineering and consulting companies which combine previous systems applied in enterprises with the new technology are more efficient and reliable in manufacturing devices thanks to better management, control or problem diagnosis. Analysing, diagnosing and then acting promptly allows for the efficient management of assets, both from the perspective of the operator and the machine itself. Efficient management favourably influences the reliability, operating efficiency, powering installations, sensors or the powering system. The applied improvements simultaneously lower the risk of system error occurrence, decreasing the exploitation costs of the building's infrastructure. The IIoT makes it possible, for example, to monitor the system of the facility critical power management through a thorough analysis of power demand in a given facility. By applying a wider range of metering and simultaneously shortening the reaction time it is possible to increase significantly the efficiency and reliability of equipment. Implementing the technologies of the Industrial Internet of Things leads to an effective, long-term improvement in the functioning of the whole facility, simultaneously reducing the exploitation costs.

\section{Smart building - stages of creation}

A smart building should be adjusted to its intended purpose of use and to the possible adaptations of this use in the future. It should comply with the specific demands and requirements of the whole group of venture participants, respectively fulfilling assumptions and goals defined in the declaration and vision of the stakeholders. Additionally, a smart building should be properly adapted to its future use, ensuring proper flexibility and scalability considered in the project. Proper adjustment of the building guarantees the smooth and efficient development of technologies and future changes in the functionality. 
According to Steve Brown, smart buildings require a range of components that cooperate mutually as a coherent whole. He describes seven key stages of designing and constructing a smart building ranging from design assumptions to the changing role of the smart building administrator in the future. The stages that he introduced, which lead to the status of a smart building, are meant to help the stakeholders plan and implement the principle of adjustment to particular purposes and future exploitation in the whole network of smart buildings.

The goal of the present paper is to determine the most important stages of creating a smart building. Defining properly the stages of a smart building development will increase the efficiency of smart building management in the future. Table 1 presents the structure and stages of building systems and components which represent a smart building according to the needs of stakeholders.

Table 1. Smart building - a diagram of designing building systems and components

\begin{tabular}{|c|c|}
\hline \multicolumn{2}{|c|}{ SMART BUILDING } \\
\hline define & design $\Rightarrow$ \\
\hline \multirow[t]{3}{*}{ Initiatives } & social \\
\hline & sustainable development \\
\hline & purpose \\
\hline \multirow[t]{5}{*}{ Experience } & comfort \\
\hline & protection \\
\hline & security \\
\hline & efficiency \\
\hline & effectiveness \\
\hline \multirow[t]{5}{*}{ System integration } & interoperability \\
\hline & functionality \\
\hline & standardisation \\
\hline & visualisation \\
\hline & operation \\
\hline \multirow{20}{*}{$\begin{array}{l}\text { United components } \\
\text { of building's system }\end{array}$} & fire protection system \\
\hline & security and monitoring \\
\hline & building's automatics \\
\hline & audio-visual system \\
\hline & lifts \\
\hline & indicators \\
\hline & electricity metres \\
\hline & electrical systems and distribution \\
\hline & parking and traffic management \\
\hline & reception \\
\hline & generators \\
\hline & heating, ventilation, air-conditioning \\
\hline & pipes and watermains \\
\hline & building's maintenance \\
\hline & resource management \\
\hline & energy management \\
\hline & integrated communication \\
\hline & access control and security \\
\hline & mobility \\
\hline & lighting \\
\hline
\end{tabular}

Source: Own elaboration based on (Brown 2016) 
1. Stages leading to the status of a smart building:

2. early planning,

3. identifying and understanding stakeholders' requirements,

4. specifying individual systems and components striving to ensure compatibility with an integrated platform,

5. failure identification and removal,

6. optimum use of control panels, virtualisation, visualisation, and data processing tools,

7. proper security,

8. new possibilities.

\section{Early planning}

The concept of a smart building should be planned at the earliest stage of the design process. In the course of smart building development, it is of key importance to prepare a detailed timetable. Once the design stage of the building infrastructure is completed, introducing potential changes is significantly more difficult and expensive. Therefore, it is important to establish a proper timetable of actions. Designers who possess detailed information on the power consumed by each element of the building's infrastructure can ensure optimum adjustment power consumption for the building, which is particularly beneficial in financial terms. Smart buildings fitted with meters in all infrastructure elements, among others, electrical switchboard, heating systems, main water pipes, vertical transport, ventilation and air-conditioning as well as irrigation systems, allow for the precise analysis of power consumption.

In a situation when the systems used at a later stage of the project are not considered and adapted to the concept of a smart building in the initial phase of designing a smart building, the changes introduced may cause an increase in investment outlays. However, introducing changes at later stages is not impossible, but the cost of constructing such a facility will significantly increase the amount of money allocated for this purpose.

\section{Identifying and understanding stakeholders' requirements}

Participants in a smart building construction project tend to have different requirements as to the building itself. Therefore, the expected results will vary depending on individual requirements and experiences. It is necessary then to analyse all the expectations and determine the requirements towards the smart building to ensure the success of the project. In the case of a smart buildings the group of stakeholders will include:

- a financial group which will require information on the influence of smart building's systems on the financial result,

- a sustainable development group, which deals with the optimum consumption of power, water, utilities and a possibility to decrease exhaust gases emission and natural resources protection, 
- an efficiency group whose purpose is to ensure building's efficiency while simultaneously ensuring the stakeholders' comfort. The efficiency group will rely on information concerning the effective use of space with a possibility to increase building's efficiency by integrating systems,

- a utility group plays one of the major roles as it is responsible for compliance with stakeholders' requirements; therefore, it needs access to all systems present in the building to react efficiently if a problem occurs. This group deals with everyday maintenance of the building and ensures access to most important information in the system,

- a safety group which will be responsible for maintaining proper control over the building, warning and activating the security system in emergency situations,

- an extra services group, which is a public communications network. It enables promoting pro-environmental initiatives for sustainable development applying, e.g., visual systems. It also facilitates moving around the facility.

\section{Specifying individual systems and components to ensure compatibility with the integrated platform}

Technical parameters of applied systems should be satisfactory enough to generate top level data. This will enable proper integration with other devices. If the equipment that does not generate data properly is used, applying technologically advanced devices may not produce the expected results the moment they are integrated with the smart platform of the building. To make the components compatible with data communication standards and logical interface used already at the device level and to enable their communication it is necessary to ensure their interoperability. Mechanical, electrical, water and sanitation installations, building automation solutions, electrical switchboards, boilers, water heaters, chillers, wind systems, fire protection systems, lighting controllers, access control systems or security systems may be fitted with an open communication protocol. In a situation when the person responsible for maintaining the proper level of comfort of the smart building tenants is notified that in one of them a cooling problem occurred, this person being able to access interactive data from all the heating systems, ventilation and air-conditioning would also be able to identify the root problem of the failure. Access to interactive data would make it possible to warn the person responsible for the control systems in the building about the possibility of a failure before it occurs. If the system is equipped with the feature of recognising and predicting failures, it can inform the persons responsible for administering the building about this fact, thanks to which avoiding the crisis and maintaining the proper level of life comfort of the smart building tenants will be possible. According to the already presented definitions, a characteristic of a smart building is the possibility to anticipate problems and automatically solve them in order to prevent a failure which could have a negative effect on the operation of the building and, as a consequence, on its tenants. 


\section{Failure identification and removal}

Failures are most frequently defined as a binary state, e.g., an air conditioner cannot be switched on, or it does not work. However, in practice, such a situation is more complex. Improper or ineffective operation of a given device may mean a failure. An example of a failure is heating and cooling a building at the same time. If such a situation occurs in a smart building, data from both devices are available within the system platform, which allows for the identification of the place where the failure occurred. The task of the applied system (Feature Driven Development - FDD) is identifying failures and diagnostics. The software identifies possible reasons for the problem before the problem becomes more intense and causes a failure affecting the whole building. FDD systems in a smart building should notify the building administrator about a possible failure before it occurs and identify the reasons for its occurrence. To identify a failure in the control sequences of a smart building, appropriate procedures and rules on failures and malfunctions need to be followed. It is also vital to develop a plan to restore the building to its proper functioning after the failure occurs. The FDD system ensures proper functioning of a smart building during and after the failure.

\section{Optimum use of control panels, virtualization, visualization and data processing tools}

After analysing and considering all the individual requirements of customers regarding the smart building and having set up all the analytic systems in the smart building's platform, another vital step is developing individual control panels that control the building for the stakeholders. The development of individual control panels will ensure the actual use of the collected data. Panels may vary in terms of design as each of the stakeholders may have different requirements regarding its visualisation and determined functions.

\section{Proper security}

One of the most important stages in creating a smart building is secure access to the network, privacy and data confidentiality. According to Article 47 of the Constitution of the Republic of Poland, privacy is defined as the right to protect private, family life, dignity and good name as well as decide about one's private life. Concerning smart buildings, it is also necessary to mention "information privacy" or "information autonomy". It defines the right of an individual to control the content and circulation of information, ensure anonymity and correct or update their data (Mednis 1999). In a smart building, the gathered data are used entirely for good purposes. Data acquisition and transfer are vital for the proper functioning of the communication system, as specific data can be linked to relevant systems, which will significantly improve the comfort of building usage. The more devices are connected to the IoT, the more probable it is that personal data can be compromised. However, total data security is impossible to achieve. 
When deciding on the use of modern technologies and deriving benefits from them, one has to take into account that their data may leak (Miller 2016, p. 104, 348-351). Conscious decisions at the initial stage of a smart building design should comply with the set of best practices. They ensure the safety of smart buildings and proper integration of particular elements when the system is operating. Several rules have to be followed, though:

- applying a unified system, primarily at the level of the device. Systems that combine various communication protocols and various technologies are more vulnerable to cyberattacks,

- documenting physical configuration of security,

- selecting open communication protocols which control devices at the device level. It would ensure the ability to control the implementation and comprehensibility of communication between devices if the producer of the system applied in the building ceased its activity,

- separating the network of communication security applications from others,

- introducing the technologies of encrypting, authenticating and authorising data,

- storing data locally and leaving it under the supervision of the building owner (from the interface level),

- cloud computing-based systems require additional security,

- data in the security structure should be granted a confidential attribute,

- default passwords should not be used,

- passwords need to be stored safely,

- device overview schedule should be developed and followed,

- transferred data need to be encrypted,

- general administrative passwords should not be applied to suppliers,

- software should be updated as frequently as possible.

There are numerous ways to optimise network security. One of them is to divide the network of a smart building into segments or to connect several of them to the system platform and the remaining ones within an independent network to preserve control over data security (Report of the European Union Agency for Network and Information Security 2014). While planning smart building's security also the standby modes of the security system should be considered. Three modes can be distinguished here:

- night mode (closing or standby mode of the system),

- transitional mode (system update before or after working hours, preparation to operation),

- day mode (full operation).

Functioning security modes of the building influence, among others, the characteristics of the existing threat profiles and the scope and nature of the selected threat. To ensure security of each mode, one should analyse and evaluate potential risks. Relationships among the threats, facility parameters and applied security require treating the building as a facility of a system security analysis. Smart building security is developed and subsequently implemented on the basis of proper algorithms of security systems design. They comprise categories of protected 
buildings and identify vulnerable points where a threat may occur. They also perform a temporary analysis of security efficiency and define the measures to neutralise threats (Mikulik 2007, p. 16-17; Szewczyk 2012, p. 140-141).

\section{New possibilities}

A smart building equipped with own infrastructure will generate a new level of applied technology utilisation in the future, including the implementation of advanced analyses, algorithms, and FDD systems. They will cause a change of roles and also tasks of the smart building administrator. The actions of the administrator will consist in the maximum utilisation of smart building's key resources, which is data. Smart buildings in the oncoming future will differ significantly from today's building, which is only technologically advanced. At present and in the future the building will include advanced mechanical, water and sanitation, and electrical installations. Regardless of the installed building optimisation systems, it is the smart building that will possess the possibility to gather large amounts of data. From consolidation on servers and desktops of all stakeholders to the utilisation of the collected and acquired data, all this will positively influence the potential of the building and enable its continuous development.

\section{The Internet of Things in smart cities and housing estates}

A house or flat we live in is only part of the space. It would be convenient if the facilities of smart building systems that we use could also be used in the housing estate or city of our residence. Smart housing estates are zones friendly to their users, which are characterised by:

- controlled access to pedestrian and vehicle traffic,

- monitoring and synoptics which receives signals about the technical condition of buildings and their surroundings,

- integration of the parking and garage systems which consists in installing a proper card under the car's windscreen allowing the system to recognise the vehicle assigned to the owner of the smart building. The access system will open the barrier and if need be it will inform the owner of the building/vehicle that rubbish is being collected from the garage or entering the garage is impossible because of the high concentration of harmful gases in the garage,

- SOS and security call system (Zygoń 2016, p. 140-143).

Smart housing estate systems integrate all the above mentioned functions. Smart cities apply ICT systems to increase the interactivity and efficiency of city infrastructure and its underlying components. From the perspective of citizens, individuals, and communities, it is a "smarter" city that is more effective and sustainable (Azkuna 2012). Smart management of housing estates and city infrastructures is becoming more and more effective. One of the examples of the functioning of a smart city or housing estate are sensors that inform where and when it is necessary to empty rubbish bins. The signal from sensors is transmitted to a sorting plant and recycling centres, decreasing the cost and optimising resource 
utilisation. Thanks to the Internet of Things it is possible to introduce innovative solutions in cities and housing estates to turn the abovementioned vision into reality. Introducing changes is a vital element of the development of the city environment, which is called Smart Cities. Schemes involve a range of sub-schemes. They usually concern smart solutions in the area of energy, waste management, transport, water management or electronic administration.

\section{Conclusions}

Determinants of a smart building demonstrate how important a role the Internet of Things plays in the whole process. No one is surprised nowadays by the number of devices connected to the network. The IoT is becoming a standard. The solutions that people use in their houses will soon expand their range. The benefits of utilising the IoT are undeniably vast and give it the nature of "industrial innovation". However, as it is the case with each new technology, this one is also accompanied by a range of challenges and threats, particularly in the area of processed data security and confidentiality. These factors may decide about the social rejection of the oncoming transformations. Control systems are based on devices and computer networks. Therefore, it should be remembered that the main threat to the systems that manage smart buildings is unauthorised access to the system through a computer network, which requires particularly meticulous security management. The Internet of Things offers a considerable potential, which can be utilised in almost every branch, from construction to finance. However, when referring to cyclical research carried out by IAB Polska Mobile one can notice that services and products connected with smart buildings demonstrate the largest increase in the implementation of the IoT concept. A challenge for the producers of domestic appliances is to increase the competitiveness and create an added value for the consumers/users. The developing technology, its pace, direction and the rate of network utilisation by the society foster the development of the Internet of Things, and thus the perspective of the development of smart houses, estates and cities.

\section{Literature}

1. Azkuna I. (2012), International Study on the Situation of ICT, Innovation and Knowledge in Cities, The Committee of Digital and Knowledge-based Cities of UCLG, Smart Cities Study, Bilbao, http://www.urenio.org/2013/01/01/smart-cities-study-ict-innovation-and knowledge-in-cities (accessed: 20.11.2017).

2. Bhavesh P. (2015), Internet Rzeczy łączy budynki, http://www.inteligentnybudynek.eu/ artykul/article/internet-rzeczy-laczy-budynki/ (accessed: 18.11.2017).

3. Brown S. (2016), Ewolucja inteligentnych budynków, http://www.inteligentnybudynek.eu/ artykul/article/ewolucja-inteligentnych-budynkow/part/5/ (accessed: 18.11.2017).

4. Clements-Croome D. (2014), Intelligent Buildings an Introduction, Wydawnictwo Routledge, USA.

5. https://buildingefficiencyinitiative.org/articles/what-smart-building (accessed: 17.11.2017).

6. http://www.rynekinstalacyjny.pl/aktualnosc/id8240,internet-rzeczy-zrewolucjonizujeinteligentne-miasta (accessed: 17.11.2017). 
7. Kiełtyka L. (2009), Wideokonferencje wielopunktowe jako jedna $\mathrm{z}$ informacyjnych technik multimedialnych, [in:] Kiełtyka L. (red.), Multimedia w biznesie i zarządzaniu, Difin, Warszawa, p. 25-33.

8. Kiełtyka L. (2017), Zarządzanie informacją i jej bezpieczeństwem w korporacji, [in:] Kiełtyka L., Kobis P. (red.), Wybrane zagadnienia zarządzania współczesnymi przedsiębiorstwami, Wydawnictwo Politechniki Częstochowskiej, Częstochowa, p. 93-106.

9. Kiełtyka L., Niedbał R. (2013), Rola ontologii w budowie systemu wspomagającego zarządzanie wiedzą w procesach e-negocjacji, [in:] Kiełtyka L. (red.), Technologie informacyjne w funkcjonowaniu organizacji, TNOiK "Dom Organizatora”, Toruń, p. 293-307.

10. Kierzkowski Z. (2013), Wieloaspektowy rozwój technologii społeczeństwa informacyjnego i przemiany strukturalne organizacji działań, "Biuletyn Organizacyjny i NaukowoTechniczny SEP SPEKTRUM”, nr 3/4, p. 4-8.

11. Konstytucja Rzeczypospolitej Polskiej z dnia 2 kwietnia 1997 r. uchwalona przez Zgromadzenie Narodowe w dniu 2 kwietnia 1997 r., przyjęta przez Naród w referendum konstytucyjnym w dniu 25 maja 1997 r., podpisana przez Prezydenta Rzeczypospolitej Polskiej w dniu 16 lipca 1997 r. (Dz.U. 1997 nr 78 poz. 483, z późn. zm.), art. 47.

12. Mednis A. (1999), Ustawa o ochronie danych osobowych. Komentarz, Wydawnictwo Prawnicze, Warszawa.

13. Mikulik J. (2007), Zarządzanie bezpieczeństwem i komfortem w budynkach inteligentnych. Część I, "Systemy Alarmowe", nr 1, p. 16-17.

14. Miller M. (2016), Internet Rzeczy. Jak inteligentne telewizory, samochody, domy i miasta zmieniają świat, Wydawnictwo Naukowe PWN, Warszawa.

15. Raport (1 December 2014), Threat Landscape and Good Practice Guide for Smart Home and Converged Media, Enisa European Union Agency for Network and Information Security.

16. Robathan P. (1989), Intelligent Building Guide, Smart Buildings Group and IBC Technical Services Ltd., London.

17. Szewczyk A. (2012), Inteligentne domy - marzeniem mieszkańców miast?, "Zeszyty Naukowe Uniwersytetu Szczecińskiego. Studia Informatica”, nr 29, p. 140-141.

18. Vermesan O., Friess P. (eds.) (2014), Internet of Things - From Research and Innovation to Market Deployment, River Publishers Series in Communications, River Publishers.

19. Zygoń O. (2016), Zrównoważone planowanie rozwoju miast - inteligentne domy, osiedla, miasta, [in:] Radek N., Stasiak-Betlejewska R. (red.), Materialne i niematerialne aspekty inżynierii produkcji, Oficyna Wydawnicza Stowarzyszenia Menedżerów Jakości i Produkcji, Częstochowa, p. 140-143.

20. Zygoń O. (2017), Wykorzystanie Internetu Rzeczy w marketingu, [in:] Synowiec A., Kruk M.S. (red.), Wiedza i technologia motorem gospodarki, Wydawnictwo Omnibuss, Częstochowa, p. 197-200.

\section{ZASTOSOWANIE INTERNETU RZECZY W OPRACOWYWANIU DZIAŁAŃ ZARZĄDZAJACYCH INTELIGENTNYM BUDYNKIEM}

Streszczenie: Artykuł ma na celu określenie odpowiednich wyznaczników inteligentnego budynku oraz definicji, która uszczegółowi wszystkie dotychczasowe pojęcia związane $\mathrm{z}$ inteligentnym budynkiem. Zaprezentowano sektory, w których Internet Rzeczy znajduje zastosowanie, oraz określono siedem etapów powstawania inteligentnego budynku. W artykule wskazano kierunki, w jakich może się rozwijać technologia informatyczna obsługująca inteligentne budynki, która do tego celu wykorzystuje rozwiązania Internetu Rzeczy. Jednocześnie przedstawiono, jak ważną rolę na każdym etapie projektowania inteligentnego budynku odgrywa współpraca projektantów i interesariuszy.

Slowa kluczowe: zarządzanie inteligentnym budynkiem, Internet Rzeczy, status inteligentnego budynku, systemy wspomagające 